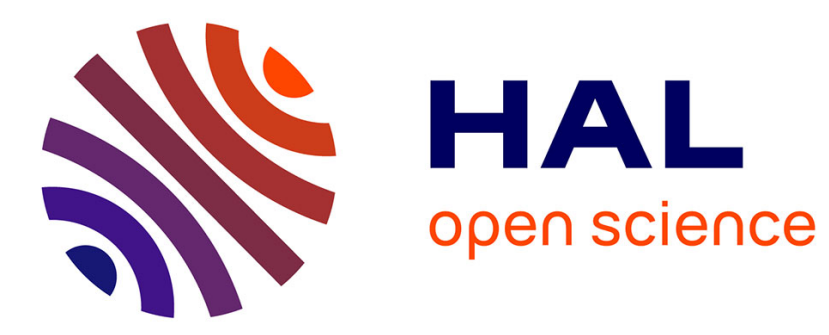

\title{
Corporate Social Responsibility and the Economics of Consumer Social Responsibility
}

Fabrice Etilé, Sabrina Teyssier

\section{To cite this version:}

Fabrice Etilé, Sabrina Teyssier. Corporate Social Responsibility and the Economics of Consumer Social Responsibility. 2012. hal-00749355

\section{HAL Id: hal-00749355 \\ https://hal.science/hal-00749355}

Preprint submitted on 7 Nov 2012

HAL is a multi-disciplinary open access archive for the deposit and dissemination of scientific research documents, whether they are published or not. The documents may come from teaching and research institutions in France or abroad, or from public or private research centers.
L'archive ouverte pluridisciplinaire HAL, est destinée au dépôt et à la diffusion de documents scientifiques de niveau recherche, publiés ou non, émanant des établissements d'enseignement et de recherche français ou étrangers, des laboratoires publics ou privés. 


\title{
ECOLE POLYTECHNIQUE
}

\section{CORPORATE SOCIAL RESPONSIBILITY AND THE ECONOMICS OF CONSUMER SOCIAL RESPONSIBILITY}

\author{
Fabrice ETILE \\ Sabrina TEYSSIER
}

November 6, 2012

Cahier $n^{\circ}$ 2012-31

\section{DEPARTEMENT D'ECONOMIE}

Route de Saclay

91128 PALAISEAU CEDEX

(33) 169333033

http://www.economie.polytechnique.edu/

mailto:chantal.poujouly@polytechnique.edu 


\title{
Corporate Social Responsibility
}

\section{and the Economics of Consumer Social Responsibility}

November 6, 2012

Fabrice Etilé $\mathrm{e}^{\mathrm{a}, \mathrm{b}}$ and Sabrina Teyssier ${ }^{\mathrm{a}, \#}$

a. INRA, UR1303 ALISS, F-94200 Ivry-sur-Seine, France.

b. Paris School of Economics, F-75600 Paris, France.

\begin{abstract}
The promotion of Corporate Social Responsibility (CSR) is likely to depend on consumers' purchase behaviors. While many consumers like the idea of social responsibility, the responsible consumption remains at a low level. This survey analyses two main barriers to responsible consumption: the willingness-to-pay for it, which relates to consumer social preferences; and the information asymmetry between companies and consumers. The economic literature shows that consumer social preferences are related to altruistic, self-image and social image concerns. Only consumers with strong social preferences and a low marginal utility of income (a high income) are likely to purchase CSR products. Moreover, purchase decisions crucially depend on the existence of labels, which truthfully identify the CSR products. Public policies may promote consumer social responsibility through education programs, enhancement of self- and social-image concerns, and careful label regulation.
\end{abstract}

Keywords: corporate social responsibility, consumer, social preferences, asymmetric information, labels.

JEL codes: L15, M14, D03, D82.

\footnotetext{
${ }^{\#}$ Corresponding author: INRA - ALISS, UR 1303, 65, Boulevard de Brandebourg, 94205 Ivry-sur-Seine cedex, France. E-mail: Sabrina.Teyssier@ivry.inra.fr.

Please note that the usual disclaimer applies: this survey does not reflect the view of the Institut National de la Recherche Agronomique or the Paris School of Economics. The opinions expressed here are under the sole control of the authors. We thank Bruno Roche for constructive discussions. Sabrina Teyssier acknowledges support of the chair FDIR (chair for sustainable finance and responsible investment).
} 


\section{Introduction}

The European Commission defines Corporate Social Responsibility (CSR) as "a concept whereby companies integrate social and environmental concerns in their business operations and in their interaction with their stakeholders on a voluntary basis" (European Commission 2001). ${ }^{1}$ It sees CSR as a tool that would help reconcile economic, social and environmental ambitions, and "wishes to give greater political visibility to CSR, to acknowledge what European enterprises already do in this field and to encourage them to do more" (European Commission 2006). CSR implies the use of social-, environmental- and health-friendly technologies during the production process and the incorporation of these technologies into the product itself. ${ }^{2}$ The spectrum of activities covered by CSR is likely to be large, as social responsibility requires that attention be paid to many stakeholders, including the company's stock holders, suppliers, employees, customers, and all individuals and communities that may be affected by its decisions.

Corporate Social responsibility is reminiscent of considerations of externalities associated to private actions in public economics. In most cases, CSR activities aim at reducing negative externalities, such as pollutant emissions or the variability of farmers' income. In some cases, positive externalities are produced, as in the financing of technological transfers to local farming communities, or school building. A standard result in public economics is that public goods are underprovided by voluntary contributions (see, among others, Bergstrom et al. (1986), Cornes and Sandler (1996), Palfrey and Rosenthal (1984) and, Ledyard (1995) for a survey). Hence, from a neo-classical point of view, favoring the development of CSR has three key advantages. It may help to solve some market imperfections, such as the externalities generated by market activities. It may increase the local provision of public goods in an efficient, decentralized, manner. A priori, state intervention is kept at a minimum, and so are market distortions. The provision by the government of public goods may for instance imply incomplete crowding-out of private provision of public goods (Frey and Jegen (2001) and Nyborg and Rege (2003)) and also of charity fund-raising (Andreoni and Payne 2003) which leads to inefficiencies.

One way to help the development of CSR is to improve stakeholders' demand for CSR. Consumers are an active part of these stakeholders whose demand for products satisfying

\footnotetext{
${ }^{1}$ Quoted in Renaut (2003).

${ }^{2}$ Such incorporation can be material as in aerosol products with no fluorocarbons, or just symbolic as in fairtrade coffee.
} 
characteristics of CSR is key. ${ }^{3}$ From the economist's point of view, 'CSR products' are both private goods and public goods. Their consumption produces some private hedonic benefits, but consumers can also derive utility from knowing that the firm is committed to care for the well-being of their suppliers and their employees or for the environment, i.e., that it produces some public good alongside the product supply chain (Besley and Ghatak 2007). Whether the consumption of CSR products leads to additional welfare gains for consumers, as compared to standard products, depends on two conditions. First, consumers must grant some value to the public good aspect of their purchase. Second, they must be well informed about the quantity of public good that has been incorporated into the product during the production process. The current survey presents the economic approach of consumers' response to CSR. It complements marketing- and psychology-based insights into this question, by focusing on the two main economic barriers to CSR consumption: (i) the consumers' subjective valuation of CSR, and (ii) the information asymmetry between companies and consumers. Understanding and breaking down these barriers is a key issue, because companies' involvement into social responsibility is partly determined by the prospect of not loosing profits or expanding market opportunities. In this perspective, we show that the development of CSR may be favored by appropriate public policies.

Although there exists no universal definition of CSR (Crane et al. 2008), in the economics literature Bénabou and Tirole (2010) differentiate three views of CSR. The 'winwin' vision supposes that CSR increases profits created by a refocus of managers on longterm profits rather than short-term profits. This vision is along the same lines as the 'strategic CSR' defined by Baron (2001) where CSR increases profits because the socially responsible firm improves her market position and then long-term profits. The 'delegated philanthropy' vision considers that economic agents use the firm as a channel for their donation deeds and then for their social responsibility. This vision is consistent with profit maximization as management takes decisions to respond to the demand. The insider-initiated corporate philanthropy' vision supposes that CSR decreases the firm's profits as here CSR comes from the management board's decision to donate and sacrifice money. ${ }^{4}$ This last vision has been

\footnotetext{
${ }^{3}$ In an analysis of the food sector, Hartmann (2011) underlines the importance for CSR development of perception and behavior of consumers regarding CSR.

${ }^{4}$ The management literature makes a clear distinction between altruistic and strategic CSR. Lantos (2001) makes a finer distinction between ethical CSR - avoiding societal harms -, altruistic CSR - doing good works at possible expense to stockholders -, and strategic CSR - good works that are also good for the business. From the consumer's point of view, it may indeed matter whether he perceives the firm involvement into socially responsible activities as purely strategic or driven by genuine altruism. Corporate social responsibility may then be motivated by two lines of arguments: pure, intrinsic, altruism on the one hand, which often requires that part
} 
attacked by economists in the same vein as Milton Friedman who considers that maximizing profits is the firms' social responsibility (Friedman 1970). Friedman argues that the decision to make CSR expenses belongs to managers while stockholders should be the deciders and then creates moral hazard from which inefficiency may ensue. The vision we adopt in this paper is essentially the 'delegated philanthropy' vision where CSR helps consumers, among other stakeholders, to express their philanthropy desire through their economic decisions. This vision is then not in contradiction with firms' profit maximization strategy. The development of CSR should then lead to efficiency gains.

In the literature, it is found that CSR may be positively correlated with financial performance, but this is not always the case (some studies find a positive relationship as Waddock and Graves (1997), no relationship as McWilliams and Siegel (2000) or a negative relationship as Wright and Ferris (1997)). Margolis et al. (2008) conducted a meta-analysis over 167 research papers and, although they find that CSR does not alter shareholder value, they conclude on the existence of a very small positive relationship between firm financial and social performance. Besides, drivers and causality of this relationship are ambiguous and not well understood (Horváthová 2010, Surroca et al. 2010). Nelling and Webb (2009) for instance show that performing firms are investing more in CSR. However, higher efficiency gains might be obtained if firms who invested in CSR would make higher profits. Indeed, this would increase future investments in CSR and therefore improve the provision of public goods. One way to make higher firms' profits is to develop consumers' demand for CSR. Hence, barriers to CSR consumption must be clearly identified and understood in order to develop appropriate consumer policies in favor of CSR.

CSR has increasingly become an important concept in public policies, corporate communication and management sciences, which have used various conceptual framework to examine consumer demand for CSR (see, inter alia, (Carrigan and Attalla 2001, Mohr et al. 2001, Sen and Bhattacharya 2001, Chatzidakis et al. 2007, Valor 2008). CSR has only recently gained interest from economists (see recent contributions of Baron (2001, 2009, 2010) and Kitzmueller and Shimshack (2012)). Consumers' responses to CSR are still scarce, perhaps because there is a wide gap between positive attitudes toward social responsibility and actual purchase behaviors. This intentions-behavior gap is driven by a desirability bias regarding CSR product attributes. It affects consumers' survey responses because declaring

of stockholders' expected benefits be sacrificed; expanding sales by a strategy of product differentiation, on the other hand. Although the consumer may be sensible to the firm's motivation for CSR, it is often extremely costly for him to verify whether the reason is based on strategy or just on preferences. 
being ready to buy CSR products or to pay more CSR products than standard products is costless. ${ }^{5}$ Opinion surveys reveal that there is a growing interest of consumers in the use of socially responsible technologies by companies (Doane 2001). According to MORI (2000), 70 per cent of European consumers declare that they are willing to pay more for a product which they perceive as ethically superior and 66 per cent declare that a CSR claim has triggered a purchase at least once in the past year (Hines and Ames 2000). Yet, market shares remain quite low: French consumers and U.S. consumers spent only 1.71 Euro and 1.14 Euros respectively per year on purchases of fair-trade products in 2005, as against 19.02 Euros for the Swiss or 4.62 Euros for the British (Poret 2007). Smith (2007) and Vogel (2005) quote a 2004 European study that found 75 per cent of respondents indicating they would modify their purchase behavior because of social and environmental criteria but only 3 per cent having done so. Besides, U.S. data (quoted in Smith (2007) and Vogel (2005)) suggest that only 10-12 per cent of consumers make any effort to purchase more environmentally-friendly products, despite more than two decades of green marketing. The current paper, by analyzing the two main barriers to consumers' demand for corporate social responsibility, aims at giving a rationale for the lack of consumers' social responsibility when it comes to real decisions.

The decision to purchase a CSR product is primarily determined by the consumer's willingness-to-pay (WTP) for CSR. The WTP is a monetary measure of her preference for this product attribute. It depends on two parameters of her utility function: the marginal utility of income and the marginal utility of CSR. The latter is determined by her 'social preferences', which refers to her propensity to internalize the effect of her own actions on others' welfare. In the analysis of consumer social responsibility, social preferences that may impact consumers' decisions are mainly represented by their generosity. We first show how social preferences affect consumers' decisions and explain that well-developed social preferences will not translate into actual purchase decisions for consumers with a high marginal utility of income, i.e. for the less well-off, as the latter reduces their WTP. Then, we focus on consumers' heterogeneity in social preferences. Following the recent advances in the economics of personality psychology, we relate social preferences to some personality traits. For psychologists, personality traits are "relatively enduring patterns of thoughts, feelings, and behaviors that reflect the tendency to respond in certain ways under certain circumstances" (Roberts cited in Almlund et al. (2011)). Interestingly, some traits have been

\footnotetext{
${ }^{5}$ Several articles specifically test the existence of this intentions-behavior gap and find evidence of it (see Auger and Devinney (2007), Bellows et al. (2008), Vermeir and Verbeke (2006)). Carrington et al. (2010) look for reasons of this intentions-behavior gap based on the literature in social psychology and consumer behavior.
} 
linked to the individual propensity to donate to charities or to engage in social activities. As personality traits have been shown to be sensitive to interventions, especially during early childhood, education is a means of favoring the consumption of ethical products (Borghans et al. 2008). We also show how consumers' social preferences are revealed by economic experiments using actual monetary incentives. This literature suggests a first explanation for the attitude-behavior gap: most (if not all) measures of attitudes toward responsible consumption are not incentive compatible. We then trace social preferences back to three important motives: altruism, self-image and social image. Self-image concerns are important for those individuals who want to reassure themselves that they are good people by contributing to the provision of public good. Social image concerns may also drive the choice of CSR products, when their consumption is a means of buying social prestige or of avoiding social stigma (Bénabou and Tirole 2010). We present empirical evidence that, in addition to pure altruism and self-image, social-image concerns strongly affect individuals' generosity, which should be more intensively used in the private and social marketing of ethical products. Last, we present applied experimental studies where consumers purchase real products that differ by their CSR attributes.

A high WTP for CSR products will lead to a purchase only if consumers have accurate information about who has made the product, and how it has been made. That the production process followed socially responsible procedures is largely a credence attribute: its presence cannot be verified by a careful and low-cost pre-purchase inspection, as it would be the case for a 'search attribute', or by the repetition of consumption experiences. ${ }^{6}$ This raises problems of information asymmetry between consumers and firms, and the latter are likely to develop strategic behaviors on the supply side of the market. Since consumers with well-developed social preferences are often willing to pay more for a CSR product, unsubstantiated claims may proliferate and cause adverse selection, whereby consumers are not able to distinguish the true from the false CSR products. As a consequence, since producing the former is generally more expensive, the true CSR products will be selected out of the market (as in the market for 'lemons' described by Akerlof (1970)). Labeling is a natural solution to adverse selection as labels are a good signaling tool. Indeed, labels increase consumers' access to information (Hadden 1986, Golan et al. 2001). Teisl and Roe (1998) explore in detail how

\footnotetext{
${ }^{6}$ Of course, in a time of global and connected knowledge, motivated consumers could check the level of CSR embodied in a good by searching for information about the economic, environmental and social policy of the producers. But, there is no doubt that consumers rarely verify these attributes for daily purchases. This would consume too much time and cognitive resources.
} 
labeling policy may improve the efficiency of markets by reducing both asymmetric information and costly search behavior. They claim that these two effects of labeling policy is beneficial to consumers as they are more informed as to the product attributes and therefore make choices more closely related to their preferences. Moreover, focusing on labels as a CSR signaling tool is relevant in the current context of a wide use of product labeling implemented by policy makers or by firms themselves. A key distinction between simple communication and labeling is that the latter requires a reputable certification agent whom consumers can trust (Caswell and Mojduszka 1996). Labels transform credence attributes into search attributes. They favor the emergence of a separating market equilibrium, whereby consumers with social preferences are matched with CSR-firms, and consumers without social preferences are matched with non-CSR firms. Although the literature on labels is mainly theoretical, we present some recent empirical results from laboratory experiments that evaluate the effect of labels on consumers under different label regulation rules. Last, we point several limits to the use of labels, which essentially relate to the credibility of labels and also to biases in the consumers' perception and treatment of information. This suggests that the proliferation of labels should be avoided (Harbaugh et al. 2011) and that labels should be unified and carefully regulated by public authorities.

The reminder of the paper is organized as follows. Section 2 focuses on consumers' social preferences. Section 3 analyzes the information issue, and the role of labels. Section 4 concludes on the role of consumer policies in the development of CSR.

\section{Consumers' social preferences}

The understanding of the heterogeneity in consumers' social preferences helps to explain, at least partly, the offer of CSR products. Mechanisms can be created to either make consumers' social preferences stronger or give incentives to consumers to behave 'as if' they had social preferences. We suppose here that consumers' social preferences are expressed by their generosity (share of income, gifts to charities, voluntarism) as it is the most relevant for consumer purchase behavior. Therefore, we first underline that there is heterogeneity in individuals' social preferences. We first detail which personality traits influence generosity and second, how individuals' generosity is expressed in the general experimental literature. In the same vein, we propose several nudges that may help develop the expression of social 
preferences. We then look more closely at consumers' decisions regarding products that have a CSR characteristic when they know it and trust it.

\subsection{Social preferences and the willingness-to-pay for CSR}

When a consumer purchases a CSR product, she makes an indirect donation, via the producer, to the beneficiaries of CSR activities (e.g. communities of farmers, employees etc.). Individuals with social preferences internalize the amount of this indirect donation in their utility function and their utility is increased accordingly.

Among a category of products, two varieties are available on the market. A standard product is characterized by a standard attribute while the CSR product includes the same standard attribute as the standard product but also a positive donation that is a measure of the CSR activity of the firm. The consumer buys $x$ units of the standard product and $d$ units of the CSR product. The consumers' revenue is $I, p_{x}$ is the price of the standard product and $p_{d}$ the price of the CSR product. The consumer's marginal utility of the standard attribute is $\alpha$ and her marginal utility of the CSR attribute is $\gamma$ that is positive only if the consumer has social preferences. The utility of the consumer depends on her consumption of the standard attribute and additionally on her consumption of the CSR attribute if she has social preferences.

By utility maximization under budget constraint, the consumer chooses to buy only the CSR product at the optimum if $\frac{\alpha+\gamma}{\alpha} \geq \frac{p_{d}}{p_{x}}-1$ when the standard product and the CSR product are perfect substitutes. ${ }^{7}$ When both attributes are complements ${ }^{8}$, the consumer has a preference for the CSR product as she buys more units of the CSR product than of the standard product if $\frac{\alpha+\gamma}{\alpha} \geq \frac{p_{d}}{p_{x}}-1$. Here, $\frac{p_{d}}{p_{x}}-1$ is the relative price premium for the CSR product (in general $p_{d}>p_{x}$ ). The ratio $\frac{\alpha+\gamma}{\alpha}$ is the Willingness-To-Pay (WTP) for the CSR attribute. It equals the ratio of the marginal utility of the CSR attribute and the marginal utility of the standard attribute. The CSR product will be preferred only if the price premium is lower than the WTP.

\footnotetext{
${ }^{7}$ The utility function we suppose is $U=\alpha x+(\alpha+\gamma) d$.

${ }^{8}$ The utility function we suppose is $U=x^{\alpha}+d^{\alpha+\gamma}$.
} 
For certain types of products, the consumer does not have other choice than consuming a certain quantity of these products category for survival (for instance, food, houses, energy...). In this case, the number of consumed products must satisfy a minimal quantity constraint. In this case, the less well-off will bind this second constraint and therefore their consumption will not be optimal regarding their social preferences but they will consume more standard products to bind the survival constraint. The more well-off will not bind the survival constraint and will therefore reach their first-best. This is also true for other products when we consider several categories of products that are non-survival because the savings made by consuming the standard product can induce the consumption of more other products. The most well-off are less constrained by it as they already sufficiently consume of other products. Therefore, if the marginal utility of income is high, which is the case for the less well-off, then the WTP is likely to be low. This may explain why the consumption of CSR products is more developed in high income households.

The purchase of a CSR product is more likely when the marginal utility of donation is high. This depends on the individual's social preferences. Before moving to the measure of social preferences in economics, the literature in psychology reveals that social preferences are related to personality traits on which education policies can act. Because a correct measure of individuals' social preferences must be based on incentive compatible mechanisms used in experimental economics that induce individuals to reveal their true preferences in their decisions, we first describe how social preferences are elicited in canonical economic laboratory experiments. We then present experimental evidence on consumers' WTP for CSR products. While the term 'social preferences' is helpful to coin a number of observed donation behaviors, it is not explicit about the motivations underlying the donations. Hence, we present three important motives that contribute to social preferences: altruism, self-image and social image.

\subsection{Social preferences and personality traits}

Bénabou and Tirole (2010) note that the social preferences are likely to be generated by some deeper psychological processes of construction and preservation of the self. ${ }^{9}$ Personality traits

\footnotetext{
${ }^{9}$ This is illustrated by Konow and Earley (2008), who find a positive and significant correlation between generosity and long-run happiness (life satisfaction) in a Dictator game, mediated by the healthiness of individual psychological functioning. In the psychological literature, healthy psychological functioning is defined by the possession of a set of personality traits, among which there is self-acceptance, i.e. the ability to
} 
are stable patterns of thoughts and feelings that are revealed by behaviors (Almlund et al., 2011). They are generally measured through psychometric tests, which use a number of questions related to thoughts, feelings and behaviors. These questions are designed so that answers tend to be correlated through a single common factor, which is the trait one wants to measure (this is called 'construct validity'). They must also discriminate between individuals, so that people do not end with the same score value (this is called 'discriminant validity'). Last, they must predict other behavioral responses (this is called 'predictive validity'). As there is no firm consensus about the traits that exhaustively define a personality, a number of different taxonomies have been proposed in the literature (see Almlund et al., 2011, about the measurement problems in personality psychology). Despite this lack of theoretical structure, personality traits are interesting from an economist point-of-view, because they may provide direct empirical measures of preferences (Caplan 2003).

More specifically, studies in personality psychology suggest that those individuals who are likely to engage in pro-social behaviors (donations, volunteerism, etc.) in the absence of material or strategic benefits, exhibit a 'pro-social personality' (Penner et al. 1995, Graziano and Eisenberg 1997, Van Lange 2000). Several specific psychometric scales have been developed to measure pro-social personality or some dimension of it: empathy as defined by (Davis 1980) (1980) (for evidence, see (Eisenberg et al. 1989, Penner 2002, Bekkers 2005, Einolf 2008, Bekkers and Wilhelm 2010)), altruism as defined by Gordon (1976) (for evidence, see (Bekkers and Schuyt 2008)), social responsibility (for evidence, see (Reed and Selbee 2002, Bekkers and Schuyt 2008)), and social value orientation as defined by Van Lange et al. (1997) (for evidence, see (Van Lange et al. 1997, Bekkers 2006)). ${ }^{10}$

According to these studies, heterogeneity between individuals about answers to psychometric scales is then correlated to heterogeneity in individuals' social preferences. Nevertheless, the value of these scales for the empirical identification of preferences is rather weak. Their predictive validity is generally assessed by correlations with hypothetical

embrace all facets of ourselves, be they positive or negative. Personality traits are more generally defined as "enduring patterns of perceiving, relating to, and thinking about the environment and oneself that are exhibited in a wide range of social and personal contexts" ((APA 2000), p. 686).

${ }^{10}$ Pro-social behaviors, which reveal pro-social personality, are also positively correlated with age, education, income, parental education and parental volunteering in the past. Mixed evidence is found for the household structure but married people or people with children are generally more pro-social. No significant correlation is found between pro-social behaviors and gender. See Bekkers and Wiepking (2011) for a survey. Nevertheless, these empirical correlations must not be interpreted as robust evidence that pro-social personality is influenced by these variables in the same way. For instance, the relationship between income and pro-social behaviors may just reflect the impact of the marginal utility of income, in a population of individuals that would have the same personality. 
decisions and, in most studies, these correlations are not normalized so as to control for the impact of factors that obviously affect individual choices, e.g. the time and budget constraints, and for the lack of monetary incentives. ${ }^{11}$ Besides, one may then wonder whether pro-social personality can be predicted by personality traits drawn from a more general taxonomy (Gergen et al. 1972). This would limit the proliferation of candidate variables, and give more solid foundations to the concept of pro-social personality. In this perspective, the literature has recently considered the 'Five Factor Model of Personality', proposed by Costa and McCrae (1992), which aims at summarizing personality by five traits. One of these traits only, agreeableness, has been found to be positively correlated to pro-social behaviors Graziano and Eisenberg (1997). Agreeableness characterizes inter-personality tendency (agreeableness consists of six dimensions: trust, straightforwardness, altruism, compliance, modesty, tendermindedness). Empirical evidence on the relationships between personality traits and social preferences as measured by real and observed action through gift behaviors in experimental games is still scarce although some recent papers tried to fill this gap. Perugini et al. (2010) find that agreeableness is positively correlated with contributions to the public good, and BenNer et al. (2004) and Ben-Ner and Kramer (2011) find that agreeableness increases donations. Becker et al. (2012) make a more complete analysis of the link between Big-5 personality traits and behavior in several experimental games. They also find that agreeableness is significantly correlated with individuals' donations.

These personality traits are therefore related to social preferences, and are likely to predict how consumers value CSR. This is important for public policy making in order to improve private contributions to public goods which are under-provided. Indeed, as personality traits have been found to be important determinants of individual choices and outcomes, public policies that influence these personality traits may be efficiency improving. Heckman and Masterov (2007), Borghans et al. (2008), and Almlund et al. (2011) provide examples of social interventions in the childhood that changed the personality of disadvantaged children and improved their socioeconomic achievements. They argue that personality traits are sensitive to investments by parents and schools. Hence, if personality traits determine social preferences, and the latter affect consumer social responsibility, then early interventions through school programs may produce some returns in terms of increased social responsibility later in life. However, we are fully aware that this may appear as an attempt to shape children preferences, which do not respect the principle of individual

\footnotetext{
${ }^{11}$ One exception is Offerman et al. (1996), who show that contributions increase in a Public Goods game with individual scores on a pro-social orientation scale.
} 
sovereignty. We have two arguments here. First, if consumer social $\underline{i r}$ responsibility produces negative externalities, then some public intervention is justified. As the World Trade Organization rules prohibit for the moment specific taxes on non-CSR products, one has to use other policy tools. Second, children preferences are quite malleable. They are shaped by parental education, schools, and the market. As long as parents are left with the option to exit, there is no reason to dismiss this proposal. ${ }^{12}$ Of course, potential negative side effects should be carefully watched. However, socio-cultural variations in traits and social preferences have not been investigated systematically, as well as the socio-cultural distribution of personality traits. Further researches are needed to assess the interest of public investments in personality traits related to social preferences.

\subsection{Experimental measures of social preferences}

In the textbook version of the homo economicus paradigm, people pursue their self-interest and seek happiness for themselves only. Greater generosity has strategic reasons only. Yet, experimental evidence reveals that the generosity of individuals is largely driven by nonpecuniary reasons. ${ }^{13}$ Experimental economics provides a controlled environment for the elicitation of social preferences that limits, if not annul, the intentions-behavior gap observed when using hypothetical choices. Two types of games are often used to elicit individual social preferences in an experimental context with real monetary incentives: the Dictator game and the Public Goods game.

The Dictator game is a simple bargaining game (see Forsythe et al. (1994), for a review of the literature). Two players face a pie that represents the total amount of money available. Player 1 (the Dictator) decides how to divide the pie between himself and Player 2 (the Receiver). The latter cannot reject this division and she knows that she will never play again with Player 1. Although Player 1 has no strategic incentive to share the pie with Player 2, more than 60 per cent of the subjects in the role of Player 1 leave a strictly positive amount to

\footnotetext{
${ }^{12}$ In France, they are already interventions at school to make children aware of the dangers of the pollution, etc. Here, we suggest that teachers should not only inform children, and try to socialize them to values of social responsibility; they should also propose optional programs, joint with social psychologists, to work on children actual behaviors.

${ }^{13}$ In The Theory of Moral Sentiments, Adam Smith views empathy and reciprocity as necessary conditions for the existence of social exchange. Humans are naturally other-oriented: "How selfish soever man may be supposed, there are evidently some principles in his nature, which interest him in the fortunes of others, and render their happiness necessary to him, though he derives nothing from it, except the pleasure of seeing it" (Adam Smith quoted by Vernon Smith, 1998).
} 
Player 2 (but this amount is always lower than half of the pie). The mean donation by participants in laboratory experiments is about 20 per cent of the pie (Camerer 2003). The Dictator game provides an evaluation of the relative importance of social preferences for Player 1, as there are no present or future monetary benefits to expect from sharing the pie. This experimental situation corresponds to a situation in which individuals decide to give to non-profit associations from which they will almost surely never receive any return in the future. Donations to charities that operate in other countries, such as The Red Cross or Médecins sans Frontières provide an 'out-of-the-lab' illustration of the Dictator game (see for instance Eckel and Grossman (1996)).

In the canonical Public Goods game, individuals are matched in groups. All individuals in the group receive initially the same endowment, and they know that they can individually invest into a public good. All individuals in the group decide simultaneously, without discussions and debates, which amount they should invest into the production of a public good. These individual contributions are added up, and this social investment is multiplied by a number higher than one and lower than the number of participants in the group. The resulting sum - the public good - is then divided equally between all group members, whatever their initial contributions. ${ }^{14}$ As a consequence, at the level of the group, the social return associated to an investment into the public good is higher than one. From the group point of view, the optimal decision is that all individuals invest their total endowment into the public good. However, for each individual, the optimal decision is to invest zero into the public good and to let the others contribute: an individual is always better off when others contribute but not him. Since the 'selfish' optimal decision is to free-ride, if individuals had no social preferences, the contribution to the production of the public good should be null. However, experimental evidence shows that most individuals invest into the production of the public good, sometimes up to their total initial endowment. The total investments into the production of the public good are on average between 40 per cent and 60 per cent of the social optimum (see Ledyard (1995), for a survey). Andreoni (1988)) shows that in repeated Public Goods games, learning (repetition effects) and strategy do not explain much of individual behaviors. The data are rather consistent with the existence of social preferences. This type of

\footnotetext{
${ }^{14}$ More formally, let $E$ be the initial endowment of player $i, d_{\mathrm{i}}$ her individual investment into the public good, and $\lambda$ the collective rate of return. Then, the individual return to investment is $\Sigma_{\mathrm{j}} \lambda d_{\mathrm{j}} / n$, where $n$ is the number of group members. Then, the resulting monetary benefit for individual $i$ is $E_{\mathrm{i}}^{*}=E+\Sigma_{\mathrm{j} \neq \mathrm{i}} \lambda d_{\mathrm{j}} / n+d_{\mathrm{i}}(\lambda / n-1)$. Since $\lambda / n-1<0$, an individual who would just like to maximize her benefit with respect to $d_{\mathrm{i}}$ will choose not to invest; she is sure that she will get at least her initial endowment. If all individuals invest their initial endowment, then they all receive $E_{\mathrm{i}}^{*}=\Sigma_{\mathrm{j}} \lambda E / n=\mathrm{E} \lambda>\mathrm{E}$ (since $\lambda>1$ ). While this cooperative strategy is Pareto-superior, it is not a Nash equilibrium of the game.
} 
experiment corresponds to situations where individuals can benefit from their own generosity, and from the generosity of others. Gifts to environmental associations such as WWF or Greenpeace exemplify this kind of situation.

Empirical evidence from the Dictator and Public Goods games suggest that individuals do no behave as selfish homo economicus. Many people accept to 'trade' private monetary gains for donations, because caring for others increase their own welfare. Such behaviors reveal social preferences. Nevertheless, not all individuals have social preferences. The experimental results emphasize the existence of heterogeneity in individuals' social preferences. This suggests the implementation of public interventions to increase the demand for CSR and ameliorate the provision of public goods.

\subsection{Opening the black box of social preferences: altruism, self-image and, social image}

Donation behaviors are observed even when the identity of dictators and recipients is anonymous in the Dictator game, or the level of individual contributions is not public information in the Public Goods game. In these games, donation behaviors are driven neither by strategic concerns nor by social image concerns, i.e., the individual reputation in the group. Here, the literature considers that social preferences are motivated by purely altruistic or selfimage concerns.

Studies of Dictator and Public Goods games traditionally assumed that behaviors were driven by pure altruism, whereby an individual's utility increases with the utility of others (Becker 1974). Andreoni (1990) argues, however, that individuals also value their individual contributions per se. This is the 'warm-glow' effect, which is probably related to self-image concerns. ${ }^{15}$ Bénabou and Tirole (2011) recently suggested a micro-foundation for image motivation. Their main hypothesis is that we do not know for sure who we are. We have several conflicting identities, and we have preferences over this set of identities: in general, we prefer to identify ourselves as generous and altruists, rather than greedy and selfish. This uncertainty can be solved by observing our own actions, which serve as signals about our own identity. As such, actions have indirect benefits, and these benefits may influence our choices, especially if our identity is quite uncertain (e.g., for teenagers and young adults). A number of

\footnotetext{
${ }^{15}$ Using the notations of footnote 7 , let $E_{\mathrm{i}}^{*}$ be the final monetary gains of individual $i$, and $\Sigma_{\mathrm{j}} \lambda d_{\mathrm{j}}$ the amount of public good that has been produced by the group. Pure altruism is illustrated by the following utility function $\mathrm{U}\left(E_{\mathrm{i}}^{*}, d_{\mathrm{i}} ; d_{\mathrm{j}}, \mathrm{j} \neq \mathrm{i}\right)=E_{\mathrm{i}}^{*}+\mathrm{v}\left(\Sigma_{\mathrm{j}} \lambda d_{\mathrm{j}}\right)$, where $\mathrm{v}($.$) is the increasing concave utility of the public good. The warm-glow$ effect can be modeled by adding a sub-utility function $\mathrm{w}($.$) , such that: \mathrm{U}\left(E_{\mathrm{i}}^{*}, d_{\mathrm{i}} ; d_{\mathrm{j}}, \mathrm{j} \neq \mathrm{i}\right)=E_{\mathrm{i}}^{*}+\mathrm{v}\left(\Sigma_{\mathrm{j}} \lambda d_{\mathrm{j}}\right)+\mathrm{w}\left(d_{\mathrm{i}}\right)$.
} 
pieces of evidence demonstrate that warm-glow and (potentially) self-image concerns are important. $^{16}$

Dana et al. (2006) propose a variant of the Dictator Game, wherein Player 1 (the Dictator) can exit the game for 90 per cent of the initial endowment. If they choose to exit, Player 2 (the Receiver) is not told about the game and receives nothing. A significant fraction of Dictators exerts the exit option. They are willing to pay 10 per cent of the endowment to leave the Receiver under a veil of ignorance, while they could merely give these 10 per cent to the Receiver. They do not want to appear unfair to the recipient, even if they do not know him and cannot be identified. They may give only to appear fair to themselves. These Dictators are not motivated by altruism, but by self-image concerns. In Crumpler and Grossman (2008), Dictators initially choose a recipient among a list of charities. Their initial endowment is $\$ 10$, and they are informed that a third party - the 'proctor' - will compensate their donation, so that the charity will receive neither more nor less than $\$ 10$. Here, pure altruists have no incentives to give, as for them only the final contribution to the charity matters and it is independent from their choice. Yet, participants donated, on average, 20 per cent of their endowments and approximately 57 per cent of the participants made a donation. The importance of self-image concerns is also demonstrated by variants of Public Goods games. For instance, Park (2000) frames the choice of the investment into the public good positively in one treatment, by telling the subjects that their contribution will make others better-off, and negatively in another treatment, by telling them that keeping the money will make others worse-off. In the first case, the positive framing of the choice renders the warm-glow benefits more salient. Individuals give significantly more than under negative framing. That framing has an impact on donations is not consistent with pure altruism. The warm-glow hypothesis can rationalize this result.

Pure altruism and self-image concerns are thus important motives for social preferences. Social image concerns - the way we think that others judge us in everyday interactions - have also received some attention. Social image is a strong incentive to engage in socially responsible consumptions. As emphasized by Bénabou and Tirole (2010), buying a hybrid car or installing solar panels on the roof of a house may be more rewarded, in terms of social

\footnotetext{
${ }^{16}$ We here present only the direct evidence based on experiments. Ribar and Wilhelm (2002) provide indirect evidence based on an econometric analysis of 'real world' data. If there is no warm-glow effect, then individuals do not value their own contribution to the public good. Hence, their contribution should fall to zero as the number of potential donators (the size of the group) increase: my marginal contribution to the public good does not matter if I believe that many other people will contribute in order to reach an acceptable level of public good provision. Using American data on private and public donations, Ribar and Wilhelm find that there is no crowding-out effect. Individual donations do not decrease with the number of donators.
} 
image, than buying an energy-efficient furnace that will never be seen. In Dictator games, making donations public increases the amounts donated. This appears clearly when only a small number of categories into which the donations fall are publicized, e.g. [1,100[, [100,500[, 500 and more. People then tend to make donations very close to the lower bound of the categories, especially for big donations. Part of these donations are undoubtedly motivated by prestige (Harbaugh 1998). Soetevent (2005) analyzes donations to churches in either 'closed' collection bags or open collection baskets and found an increase of donations by 10 per cent when baskets are used. An increase of donations is also observed in laboratory Dictator games when donations are made public (Ariely et al. 2009). Removing the anonymity of individual investment choices in Public Goods game increases the contributions (Andreoni and Petrie (2004) and Rege and Telle (2004)).

The effect of social image on socially responsible consumptions depends on the market share of CSR products. This has some consequences for consumer policies. Many states have implemented subsidies to environmentally responsible consumption, especially for durable goods (cars, eco-labeled houses, etc.). Social image concerns imply that these subsidies are less useful when few people or, on the contrary, almost everyone participate to consumption. When few consumers opt for social responsibility, social distinction is still an important motive for doing it. This is all the more true, that CSR products have generally higher prices. ${ }^{17}$ When almost all consumers choose social responsibility, then there is a stigma attached to not doing it and peer pressure may force consumers to adopt CSR-products. ${ }^{18}$ However, social image concerns alone are unlikely to generate a significant move of consumers toward CSR products. For this to be observed, the real price of CSR products should fall, as a consequence of a rise in income for the less well-off consumers, or a fall in the production costs of CSR products. A fall in cost may somehow contradict the objective of CSR, if it is obtained at the expense of the corporate employees or suppliers. Social psychologists have long recognized that a number of altruistic behaviors are influenced by internalized standards of conduct. "People sometimes act altruistically because this is the right

\footnotetext{
${ }^{17}$ The consumption of CSR products does not only signal how attached to the public good the individual is, but merely her social status. Social image concerns may thrust the adoption of socially responsible ways of consuming, at least for well-off consumers, but they also generate negative externalities in the short-term: if socially responsible consumption buys social prestige, then those individuals who cannot afford these material signs of social responsibility may feel worse.

${ }^{18}$ Vermeir and Verbeke (2006) find in a sample of 456 young consumers surveyed about their attitudes and intentions towards sustainable food products that experiencing social pressure from peers increases intentions to buy despite negative attitudes. Hence, social pressure can be a driver of purchase even if the consumer likes less the CSR product than the standard one. DellaVigna et al. (2012) show that social pressure is an important determinant of charitable giving.
} 
thing to do in a given situation. On other occasions, however, they might help someone else because they empathize with him" (Berkowitz 1972). Social image concerns are thus related to social norms of consumption. As such, the expression of altruistic preferences is likely to differ from one social group to another. The higher social classes will perhaps value donations to humanitarian causes and the consumption of fair-trade or organic goods, while members from the lower and middle classes may attach more importance to the time one gives to the community. ${ }^{19}$ If this is the case, then games with money incentives will tend to underestimate the altruism of the latter as they cannot express it in an experiment where donations are only monetary.

A realistic approach to the measurement of social preferences should take into consideration the social context of choice (social norms, membership of a specific social group, values and moral norms) and should disentangle the three main motives underlying social preferences: the self-image concerns, the social image concerns and altruism. As individuals' self- and social-image concerns seem to matter a lot, public or private policies can use those concerns to promote generosity of consumers and then sustainable consumption. Additionally, social preferences depend on the recipient's identity and behaviors, and on values and moral norms. For instance, a consumer who believes that people in poverty "have just what they deserve" will tend to give to different causes than the one who believe that poverty is just bad luck (see Fong (2007) for experimental evidence in a Dictator game). Wymer (1997) and Bennett (2003) find that personal values are an important determinant in the choice of the charities to which individuals choose to give. For instance, someone who places a higher importance on health is more likely to give to charities that are engaged in health programs. Public policy could try to make information campaigns about a specific cause among people who share this cause.

\subsection{Consumers' willingness to pay for CSR products}

In general setting experiments, heterogeneity of consumers' social preferences is found out. Nevertheless, these studies are implemented in a context without any framing which asks the question of the external validity of experimental results (Levitt and List 2007) and their application to purchases of real products. Some experiments do focus on consumers'

\footnotetext{
${ }^{19}$ Simon (1993) already noted that identification to a community favors altruistic behaviors toward the other community members.
} 
generosity when it comes to purchases of real products. The consumer WTP for CSR labels can be elicited by two types of methods. ${ }^{20}$ First, there are methods based on hypothetical choices. Several varieties are presented to individuals. They are differentiated along a number of dimensions, including the presence of a label and the price. Individuals then state their preferred choice and an econometric analysis of their answers produces estimates of the WTP for the attribute 'label'. This method is costless and can be used as a first step analysis of the potential effects of a labeling policy on consumers' behaviors (see Hartmann (2011)). One important drawback is that the estimated WTP is certainly biased, as answers are purely declarative. We imagine well that, for reasons of social desirability and because it is only cheap talk, most consumers exhibit a strong preference for CSR. Experimental auctions are a second type of method. Here, the subjects have to make choices that have actual monetary consequences, and they often go back home with the products for which they have expressed a strong preference. These methods yield, in theory, unbiased estimates, because they are based on monetary incentives. However, they cost more in time and money. As such, they generally involve smaller samples and are less representative of the general population. ${ }^{21}$

Studies based on hypothetical choices conclude unambiguously that consumers are ready to pay more for labeled products. For instance, Blend and van Ravenswaay (1999) find in a representative survey of American households that over one-third of consumers would be willing to pay a premium per pound of $\$ 0.40$ for eco-labeled apples, where the label certifies that the apples have been produced with sustainable agricultural practices. As the willingness to pay for a food product is highly correlated with its perceived hedonic quality, Loureiro et al. (2002) also elicit preferences for an eco-label, but they control for the consumer's perception of the hedonic quality of the eco-labeled apples. They find a much smaller premium of $\$ 0.05$ per pound only for the latter. McCluskey and Loureiro (2003) replicate this study with a different label that indicates whether the apple has been produced by farmers who provide fair and safe working conditions. Again, although answers reveal that consumers are willing to pay a premium for CSR apples, they also condition their purchase to the perceived hedonic quality of the apple. However, it is also found that the most important

\footnotetext{
${ }^{20}$ A third method that we will not detail in the current survey would be to analyze actual purchase behaviors by estimating econometric models of demand for differentiated products. This requires that varieties with labels be already purchased and, for reasons of statistical robustness, that a large number of purchases be observed. This method produces estimates that can be used to simulate the impact of labeling a product that was previously unlabeled.

${ }^{21}$ These methods are also used to identify the WTP for organic or Genetically Modified (GM) food. Although there might be an altruistic dimension in the preference for organic and the refusal of GM food, the health dimension is by far the most important (see, inter alia, (Huang 1996), (McGarry Wolf et al. 2002)).
} 
characteristics of an apple in consumers view are its taste, its quality and its freshness, while how the apple was grown is next to last. Some hypothetical choice studies also show that the effect of labels vary with levels of performance. Hicks (2006) tests the impact of a fair-trade label on consumers' WTP for coffee, when the percentage of poor farmers participating to the production process vary. ${ }^{22} \mathrm{He}$ finds that consumers are willing to pay a premium for the labeled coffee over the unlabeled coffee, but only when the percentage of poor farmers included in the program is high enough. In a similar study, Basu and Hicks (2008) show that, for a given percentage of participating farmers, the consumer WTP is positively related to the income guarantee associated with the label, but only up until a critical level. After this point, the WTP decreases. They explain this result by a consumer aversion to poverty and relative deprivation. This would lead consumers to consider that the farmers excluded from the program are worse off when the income guaranteed to the farmers included into the program is too high.

Experimental studies often use the Becker-DeGroot-Marschak (BDM) auction mechanism (Becker et al. 1964) to determine the WTP of subjects for a specific product (see for instance (Wertenbroach and Skiera 2002, Noussair and Ruffieux 2004, Bougherara and Combris 2009). In a BDM auction, a product is presented to the subjects with a description of its characteristics. One key point is that this description can be manipulated by the experimentalist, in order to identify the causal effect of information on individual behaviors. After the presentation of the products, all participants must simultaneously submit a monetary offer, in an envelope. They cannot communicate with each other, in order to avoid social interaction effects. The experimentalist then chooses a price at random in a distribution of prices that has been given to the participants before the experiment. Participants who have submitted an offer higher or equal to the price randomly drawn by the experimentalist receives the product and have to pay the price drawn. Participants who have made an offer lower than the price drawn by the experimentalist do not receive the product and pay nothing. In this set-up, if an individual submits an offer that is much higher than her true WTP, then she is at risk of paying a lot for a product she does not really like. If her offer is much lower than her true WTP, then she is at risk of not getting the product even if she would like to. Her interest is to submit an offer that is equal to her true WTP. Using this method, Tagbata and

\footnotetext{
${ }^{22}$ There are also some studies on fair-trade coffees based on hypothetical choices. (De Pelsmacker et al. 2005) (2005) find that Belgian consumers are ready to pay a premium of $10 \%$ for a fair-trade coffee. (Loureiro and Lotade 2005) (2005) conducted a survey in four locations in the State of Colorado in the U.S., which yields similar results.
} 
Siriex (2008) test the effect of an organic label and a fair-trade label on the WTP for chocolate tablets. They constructed their experimental set-up in order to disentangle the effect of the label from the effect of taste, and the effect of social preferences (the fair-trade label) from the effect of health preferences (the organic label). The new information - "having a label" increases the subjective value of the labeled tablets. However, some heterogeneity in individual preferences is observed. For about half of the subjects, labels do not matter when they make their offer, while it is an important choice criterion for the remaining half. Hence, the degree of social preferences exhibited by individuals seems to be a discrete individual characteristic - to be altruistic or not to be - rather than a continuous characteristic.

A significant minority of consumers are ready to pay a premium for products with CSR labels. However, a number of them seem to consider CSR labels as a sign of hedonic or health quality. A majority of consumers have a low WTP for CSR, because they have weak social preferences, or their marginal utility of income is higher. The implementation of third-party certification or firm reputation is likely to let consumer social preferences express on the market through their purchase behavior. Market segmentation is likely to result that raises strategic issues for firms.

\section{The impact of labels}

Consumers may well have social preferences. If they cannot recognize a CSR-product from a non-CSR product, then consuming the former instead of the latter will bring them no additional pleasure. Differing from other product characteristics such as appearance, flavor or durability, the environmental or social quality of the production process is rarely observed by consumers. CSR attributes are credence attributes and then generate information asymmetry as this type of attributes cannot be judged by the consumer neither before the purchase nor after consumption or only at a prohibitive cost (Darby and Karni 1973, Nelson 1974). The asymmetry of information between sellers and consumers implies that the latter are not able to purchase the goods that best match their preferences. As a consequence, there are welfare losses, which are likely to be larger for those individuals who have a higher WTP for CSR attributes (Bonroy and Constantatos 2004). Therefore, the market equilibrium is not efficient in the sense that consumer welfare could be improved without affecting firms' profits. This is indeed a general result from the neo-classical approach to consumer economics: consumers 
are always better off when they have more information (Teisl et al. 2001). Consumers need to be informed about the type of product they purchase in order to make optimal choices. ${ }^{23}$

Signaling may be used as a tool to limit this information asymmetry between consumers and firms. We analyze the effect of signaling on the market equilibrium, focusing on whether labeled products co-exist on the market with unlabeled products (we call this a separating equilibrium). Indeed, labels improve the efficiency of markets by reducing both asymmetric information and costly search behavior (Teisl and Roe 1998).We also consider the consequences of the credibility of the label, which comes down to consider the impact of the credibility of the certification agency and of firms' reputation on the market equilibrium. Screening activities of consumers or intermediaries like NGOs impact the market through their potential influence on firms' reputation.

\subsection{Labels to disclose corporate social responsibility}

Several signaling tools may be used by firms to signal their Corporate Social Responsibility. For instance, sustainability reports may be constructed by firms to signal their degree of social and environmental responsibility. Many OECD countries have adopted since the 2000s legislations requiring firms to report on their CSR activities. Nearly $80 \%$ of the largest companies worldwide (G250), and $45 \%$ of the 100 largest companies of 22 industrialized countries (N100) issued CSR reports in 2009 (see KPMG (2008)). Although these sustainability reports becomes a requirement by the legislation to inform consumers' about firms' involvement in CSR, consumers are likely to forget conclusions of such reports when they make their purchases in shops. The regulation of production processes by production standards and norms is another way to reduce consumers' uncertainty about the type of product they purchase. All States have laws that oblige producers to respect some production standards. However, it is not easy to define standards that correspond to all producers and it is even more complicated to find international social standards that would be accepted by all countries.

The widespread alternative is a market approach based on voluntary certification and the labeling of production standards. Labeling CSR is a way to differentiate products on purchase points. It is a low-cost means of giving consumers direct information (National Academy of

\footnotetext{
${ }^{23}$ Polls show that European consumers would like to know more about the origin and the production process of food products, and they would appreciate to have this information on the packaging (Guillon and Juliot 2001).
} 
Sciences 1991). Labels help to restore the symmetry of information or at least reduce the asymmetry of information between sellers and consumers. As such, they may lead to market efficiency gains and increase consumer welfare (Golan et al. 2001). ${ }^{24}$ There are two classes of labels: 'public labels' and 'private labels'. ${ }^{25}$ Although both are voluntary, the first is based on third-party certification and the second on self-regulation. Baksi and Bose (2007) and Roe and Sheldon (2007) emphasize that firms prefer private labeling but consumers prefer public labeling. Certification nevertheless costs more than private labeling.

We define public labels as labels that are certified by a third-party on the basis of criteria that are supposed to be known by consumers. Certified standards are included in third-party certification labels. This third-party can be a governmental agency ( $c f$. the Blue Angel label in Germany or the EU eco-label) or an independent organization ( $c f$. the Fair-Trade label or the AB organic label in France). Regarding CSR, the most well-known public labels are the fairtrade labels Max Havelaar and Transfair, which guarantee good working conditions for small farmers in the developing world. Many other fair-trade labels exist and they are all certified by an international organization named "Fairtrade Labeling Organizations" (FLO). Labeling standards include a minimum price for producers and a fair-trade premium, safe working conditions, and the prohibition of child labor and discriminations.

Private labels characterize self-regulation (see Baron (2001, 2009, 2010)). They often take the form of 'logos' incorporated in the packaging by the producers or the retailers themselves, claiming messages such as "This product respects the environment" or "We valorize long-term relationships with producers". Advertisement is also included in this class of private labels. These claims are unsubstantiated, since they are not certified by a third-party and cannot easily be verified. Corporate branding is another type of signaling based on private labels. Firms' reputation is key here. Indeed, corporate branding is valuable only if consumers trust the brand and they are careful about information on its reputation. The effect of reputation goes through screening activities taken by the less informed party (consumers or NGOs) to obtain information about the firms' social and environmental responsibility. These activities can be product tests and guides, CSR ratings or boycotts campaigns. Comparative corporate tests are an instrument specifically developed to ameliorate this informational

\footnotetext{
${ }^{24}$ Labeling is also an efficient way to reveal consumer preferences for CSR in a non-experimental context. Of course, purchase behaviors will not reveal the social preferences of all consumers, as there are financial and hedonic barriers to the purchase of CSR-products. Although people with low income tend to give more (in proportion of their own income) to social causes, they are less likely to purchase goods with environmental or social labels because of their prices or their tastes. See also the Section 3.3 about the segmentation of the market. ${ }^{25}$ See Kuhn (2005) for details on these two forms of labeling.
} 
dilemma and generate more transparency about responsible corporate behavior. CSR ratings also play an important role in the market for social responsibility, in particular because it matters for investors wishing to invest in the most responsible firms, and socially responsible investing (SRI) has experienced a tremendous increase in Europe over the past decade (for basic descriptive presentations of CSR rating and of SRI markets see e.g. Schäfer et al. (2006), Eurosif (2010) and US Sif (2010)). Consumers may also organize themselves when the reputation of the firm is lowered. They may for instance plan boycotts campaigns. The fear of consumers' boycotts therefore affect firms' decisions (see e.g. Feddersen and Gilligan (2001) and Glazer et al. (2010)).

\subsection{Effect of labels on market equilibrium}

As some consumers are willing to pay a positive premium for purchasing CSR products instead of standard ones, firms may have some strategic advantage at increasing their commitment to social responsibility. Margolis et al. (2008) uncover evidence of a positive correlation between the degree of CSR of companies and their financial performance. Frooman (1997) counts 27 studies in which companies known as socially irresponsible suffered from a loss of wealth. CSR investments have also been linked to the ability to secure greater access to capital funds. In the U.S., in 2003, 11 per cent of the professional funds were managed in portfolios that screen for ethical, environmental and other socially responsible practices (Social Investment Forum 2003). Adopting a socially responsible attitude seems to be beneficial to firms, and this may explain the growth of CSR investments. However, correlation is not causality, and it seems difficult to test with available business data whether adopting CSR practices has a positive impact on performance (Cavaco and Crifo 2010). It may indeed be the case that more competitive firms are more able to adopt CSR standards, or that a third factor - for instance, operating in an innovative sector or well-developed shareholders' social preferences - explains both the company's ability to perform and its choice of social responsibility. There is a clear lack of causal empirical evidence about the link between CSR and companies' profits and strategies. As a consequence, we here present some selected results from theoretical studies. They yield predictions about the consequences of signaling on the market equilibrium, i.e. the companies' supply and profits and the consumers' welfare gains. 


\subsubsection{When labels provide perfect information}

Let us consider a market wherein products can differ by their prices and by a one-dimensional credence attribute, e.g. the 'CSR attribute', that can be signaled by a label. We assume first that the information provided by the label is perfect. We will discuss the quality and the trustworthiness of the certification process in the next subsection.

A first set of papers uses Hotelling's spatial competition paradigm to analyze corporate strategies. For instance, Conrad (2005) assumes that the consumers are randomly distributed along a $[0,1]$ segment that represents their heterogeneity in social preferences: the closer to 1 , the stronger the social preferences. There are two firms, which have to choose their localization on this segment, i.e. the amount of 'CSR attribute' they want to incorporate in their product, and a supply price. Given the price and the quality of the products, the consumers choose a firm in order to maximize their utility. The latter decreases with the price paid and their distance to the firm localization, as it is always the case in spatial competition model. The author also assumes that consumers are concerned with their social image (cf. Section 2.2.). A separating equilibrium is found and, unsurprisingly, the market share and the price of CSR products increase when social image concerns are more important for consumers. This basic framework can be enriched by introducing some heterogeneity in the cost structure of firms and by endogeneizing accordingly their labeling decisions. As firms must make investments in order to be certified, the firm with the most efficient cost structure will be more prone to invest in social responsibility (Crampes and Hollander 1995, Amacher et al. 2004). Certification costs may also have a strong impact on market segmentation. For instance, Auriol and Schilizzi (2003) show that the label is a credible signal for corporate social investments only when the certification cost is high enough. This raises fairness issues in terms of equality: when certification costs are important, the prices of labeled products are rather high. As a consequence, a separating market equilibrium with both CSR and non-CSR products is much less likely to appear when consumers are poor or when the market is not very developed, even if most consumers have strong social preferences.

A second set of articles models CSR as the joint production of public good (or curtailment of public bad) and private good. For instance, Besley and Ghatak (2007) analyze a competitive market with identical firms. Consumers have heterogeneous preferences over a public good and a private good, and producing the CSR-product (a joint public and private good) implies higher marginal costs. At the equilibrium, some firms will produce the private good only for consumers who have weak social preferences. Other firms contribute to the 
production of the public good and charge a higher price for the private good to reflect their contribution to the public good. Competition guarantees that the price charged by the CSR firms exactly finances the cost of the public good, since the price premium paid for the CSR product is exactly equal to the average consumer WTP for the public good: firms cannot charge a higher premium (competitors will take over its market), and cannot charge a lower premium either (make losses). Once again, only those consumers who have strong social preferences and a low marginal utility of income buy the CSR product. This separating equilibrium improves the social welfare as compared to a situation where only private goods are produced.

An experimental study by Rode et al. (2008) mirrors the modeling framework presented above. They organize a market where three firms and six consumers exchange units of a virtual good, which are converted into real money at the end of the game. One of the three firms has a higher cost of production because it complies with the conditions of an internationally recognized NGO fighting child-labor. This is the socially responsible firm, and the individual who is committed to play this firm makes a true donation to the NGO at the end of the game. As expected, this player offers higher prices than individuals playing the firms with the lower costs, whether labeling is possible (the research treatment) or not (the baseline treatment). When labeling is not possible, the consumers purchase at the lowest price, even if they know the costs of production for each offer. When labeling is possible, i.e. when consumers learn why there is a high-cost offer, then it gets higher market shares. There is an important heterogeneity in the label effect that may reflect differences in social preferences.

\subsubsection{The credibility issue of labels}

The objective of public labeling through third-party certification is to provide objective and correct information. When third-parties can monitor perfectly all aspects of the company's production process declarations, and when the rate of information disclosure is high enough, the label is perfect enough (McCluskey 2000). Nevertheless, frauds can be observed even when the certification agency is honest, because monitoring costs alter the quality of certification. ${ }^{26}$ The latter depends on the probability of controlling the firm and the intensity of the control and audit procedures. These two parameters are set by the certification agency. If the latter are too low, some firms will have an interest to try to cheat to get the label, even if

\footnotetext{
${ }^{26}$ Hamilton and Zilberman (2006) illustrate why labeling fraud must occur in equilibrium.
} 
they do not comply with the criteria asked by the certification organization. There is a probability of green-washing brown firms that can affect the credibility of all labels. ${ }^{27}$

Another problem of adverse selection may appear if the certification agency has opportunistic behaviors that induce skepticism about the label trustworthiness. The role of the trustworthiness of the certification agency is key regarding the effect of the label on consumers' behavior. The reputation of the certification agency affects the consumers' trust (Caswell and Mojduszka 1996). Depending on the frequency and accuracy of controls, public labels can be more or less trustworthy. One solution to ensure trust in labeling is to control the certification agencies themselves (McCluskey 2000). It then appears that all certifying organizations do not have the same trustworthiness regarding the efficiency of their monitoring procedures. For example, Albersmeier et al. (2009) find that the reliability of the German third-party certification of food chain safety is very heterogeneous, because the auditing procedures have not been standardized. An important issue is that there is some competition between certification agencies, and this may have consequences for consumers in terms of higher prices or lower confidence in labels. Hvide (2009) considers a market, where certification agencies compete for firms who want to apply for a label. A key condition of efficiency is that the certification fees correctly reflect the difficulty of the tests. In this situation, the price premium paid by the consumers is higher than when the certification agencies have the same standards and tests. Therefore, consumers must support the costs for the guaranty of quality and trustworthiness of the certification process. However, the problems of label credibility are mitigated in theory when one introduces reputation effects. In this case, a firm that cheats and is detected is likely to disappear from the market. The probability of detection has a clear deterring effect (Besley and Ghatak 2007).

As private labeling does not require any certification by a trustworthy organization, consumers do not know the true degree of compliance of the company with their own environmental and social norms and values. Hence, firms have a strategic incentive to cheat and claim that they are highly involved in CSR, even if they are not. There are expected benefits from cheating, which include higher market shares and higher prices, for no costs since they do not have to design and engineer an environment- or people-friendly production process. This generates an adverse selection problem. A number of consumers will end by considering that all private labels just represent 'green-washing' (especially if there are press

\footnotetext{
27 A discussion on the certification system Fairtrade Labeling Organizations International (FLO) and its credibility can be found in (Ballet and Carimentrand 2006) (2006).
} 
reports about opportunistic behaviors). True CSR firms will be driven out from the market, as they have higher production costs, and the true CSR products are likely to disappear. From a theoretical point-of-view, this adverse selection problem may be solved by third-party certification, or by the combined effect of market discipline, reputations and the awareness of media, NGO activists and consumer associations.

Firms' reputation is the basic of corporate branding and then may help to restore some trust from consumers regarding firms' private labeling. The newspaper The Economist suggested in an answer to the 'No-Logo' movement that brands play the same signaling role as labels, because "they make firms accountable to consumers", and "brands of the future [...] will also have to signal something wholesome about the company behind the brand [...] social responsibility". ${ }^{28}$ If a private CSR label becomes a salient element of the brand identity, then the producer faces potential reputation costs if it cheats. One key element here is that the reputation costs will depend purely on consumer reactions to changes in company reputation. The reputation effect is likely to dominate in markets with a limited number of competitors, barriers to entry, and well-established brands. Here, the rents are so high that the firm will not take the risk to lose its position.

An important limit to the trustworthiness and effectiveness of labeling strategies is that a label is generally a small part of the information set used by consumers when they have to choose between different varieties of a product. The information available at the time of purchase also includes prior experiences, media advertising, word-of-mouth information, nutritional labeling, brand reputation, other quality labels, all informational cues that are displayed on the packaging (colors, shape, health claims, etc.) (Caswell and Padberg 1992). Given the amount of information that is available, labels may not always be correctly perceived by consumers. This is all the more true that there are now many labels on the market, with subtle differences between them. ${ }^{29}$

Marketing research has demonstrated for a long time that the accumulation of information creates a 'halo' effect, whereby individuals draw an impression of a product from

\footnotetext{
${ }^{28}$ See The Economist, "The Case for Brands" (http://www.economist.com/node/771049/print) and "Who's wearing the trousers?" (http://www.economist.com/node/770992/print), September $6^{\text {th }} 2001$, from the print edition.

${ }^{29}$ In France, there are three organic labels, which are simultaneously a health and a CSR-guarantee: AB, the EU organic label, Demeter. The AB and EU labels tolerate the use of GMO in the foodstuffs for stock breeding. Regarding CSR, there are five labels at least: Max Havelaar, the Marine Stewardship Council, the CCP, Nature et Progrès, and the "Agriculture Raisonnée" (sustainable agriculture). There are some private retailer labels, such as "Agir pour l'Environnement" ("Act for the Environment», retailer: Carrefour). A number of quality labels guarantee the hedonic quality of the products, such as the AOC, the Label Rouge, and European labels guaranteeing the region of production.
} 
a few pieces of information, and use this impression to infer the value of some other attribute. For instance, Tagbata and Siriex (2008) report that the WTP for chocolate is the same whether the product has an organic label, a fair trade label, or both, although the organic and fair trade labels refer to very different attributes. The effects of both labels are not additive and all that matters is to have a label or not (see also Ruffieux (2004)). This implies that there is a cluster of consumers with social, environmental and health preferences, which interpret labels as an overall quality grade, without making any distinction between the health, and the CSR aspects of quality. The 'halo' effect is potentially damageable if it is used by marketers to manipulate consumer perceptions. Chandon and Wansink (2011) present experimental evidence from the marketing literature that unregulated health claims about a specific nutrient are enough for leading consumers to believe that the product scores well on all nutrition aspects. While evidence for the use of a CSR halo by firms is lacking (the so-called greenwashing), this justifies a careful regulation of CSR claims. The 'homo economicus' is better-off with more information, because his/her unlimited cognitive capacity protects her from such errors of perception. But the 'homo sapiens' may perhaps be worse-off, because of systematic perception biases. In the literature in economic theory, Harbaugh et al. (2011) show that uncertainty creates consumers' confusion and label proliferation aggravates this effect.

As a consequence, truthful labeling is a necessary condition for the development of a significant market for CSR products that may satisfy consumers with well-developed social preferences. But, it is not a sufficient condition, especially if labels and claims proliferate. This call for the harmonization and unification of CSR labels, possibly at the EU level. ${ }^{30}$ In addition, labeling is necessary but not sufficient because the effect of CSR information also depends on the consumers' perception of "congruence between their own characters and that of the company" (Sen and Bhattacharya 2001). If they have well-developed social preferences and perceive a discrepancy between the 'nature' of the firm (shaped by its reputation and history) and its social initiatives, then they tend to perceive the latter as hypocritical or purely strategic (Becker-Olsen et al. 2006). This may decrease their willingness to purchase the product, even if corporate social efforts and investments have been awarded by a label. As a consequence, a complementary strategy is to develop a brand, whose name is enough to suggest several attributes (including CSR). One example is "Body Shop", which is associated to good practices in terms of research and development and choice of raw products. But while

\footnotetext{
${ }^{30}$ One leading example of harmonization is the EU eco-label for industry and technology, that is already awarded for more than 25 product groups (but not food). See http://ec.europa.eu/environment/ecolabel/.
} 
labeling is relatively easy to implement on the short term, brand building is probably a longer term strategy (20 years or more).

\section{Conclusion}

Approaching CSR from the consumer point of view provides rationales for the existence of a market for CSR products. In this view, the two main ingredients that may sustain the production of CSR goods are consumer social preferences and information disclosure of CSR characteristics of products. Regarding the first ingredient, the literature shows that consumers have heterogeneous social preferences and consumers with strong social preferences are more likely to purchase CSR products. Moreover, as socially responsible consumption is driven by social image concerns, in addition to altruism and self-image, developing on strong social norms of consumption may be sufficient to trigger the purchase of CSR products, even if individuals are not altruistic. Social image concerns may even drive non-CSR firms out of the market.

The disclosure of CSR information is key for the existence of CSR as CSR is a credence attribute of products. The consumption of CSR products is associated to additional benefits for consumers with social preferences in terms of utility/well-being only if the consumer is aware that the product has been produced according to CSR principles. This requires that a label indicates the CSR quality of the product. In fact, empirical studies reveal that a significant fraction of consumers are ready to pay more to consume products with CSR labels. Therefore, a separating market equilibrium may emerge whereby consumers with strong social preferences (and high income) buy CSR products and consumers with weak social preferences (or low income) buy non-CSR products. However, the credibility of the CSR label is an important issue. Some firms may cheat and look for green-washing, which generate an adverse selection problem if the label is not trustworthy. Public labeling is always better than private labeling if firms' reputation does not play any role. The credibility of public labeling requires that certification agencies monitor correctly firms, and be themselves monitored. Studies on the untrustworthiness of certification agencies also suggest that monitoring costs and competition among the certification agencies may deteriorate the market efficiency. Corporate branding based on private labeling may also lead to efficiency if screening activities of consumers are a threat for firms' reputation. 
Truthful labeling, either public labeling with third-party certification when certification agencies make sufficient controls or private labeling with firms' reputation that is equivalent to corporate branding, solves the 'lemon market issue' and therefore leads to efficiency gains. Consumers receive more information and are then more likely to make purchase decisions that match their social preferences. It is hence optimal that consumers with social preferences buy CSR products, i.e. labeled products, at a higher price. Indeed, CSR products worth a price premium as they are more costly to produce than non-CSR products. However, while a separating equilibrium increases social welfare, it is not sufficient to drive-out of the market unethical firms. Government policies, combined with labeling, should help to eliminate these firms (see Davies (2005), about child labor). A sufficient increase of market shares of CSR products and a significant change in consumers' demand may help too. Although potential drawbacks should be carefully analyzed, a first solution would be to invest in children social preferences and a second solution would be to subsidize CSR products. 


\section{Bibliography}

Akerlof, G. A. 1970. The market for" lemons": Quality uncertainty and the market mechanism. The quarterly journal of economics 84:488-500.

Albersmeier, F., H. Schulze, G. Jahn, and A. Spiller. 2009. The Reliability of Third-party Certification in the Food Chain: From Checklists to Risk-oriented Auditing. Food Control 20:927-935.

Almlund, M., A. L. Duckworth, J. J. Heckman, and T. Kautz. 2011. Personality Psychology and Economics. NBER Working Paper 16822.

Amacher, G. S., E. Koskela, and M. Ollikainen. 2004. Environmental Quality Competition and Eco-Labeling. Journal of Environmental Economics and Management 47:284306.

Andreoni, J. 1988. Why Free-Ride? Strategies and Learning in Public Goods Experiments. Journal of public Economics 37:291-304.

Andreoni, J. 1990. Impure altruism and donations to public goods: a theory of warm-glow giving. The Economic Journal 100:464-477.

Andreoni, J. and A. A. Payne. 2003. Do government grants to private charities crowd out giving or fund-raising? American Economic Review:792-812.

Andreoni, J. and R. Petrie. 2004. Public goods experiments without confidentiality: a glimpse into fund-raising. Journal of public Economics 88:1605-1623.

APA. 2000. Diagnostic and statistical manual of mental disorders: DSM-IV-TR. American Psychiatric Publishing, Arlington, VA.

Ariely, D., A. Bracha, and S. Meier. 2009. Doing good or doing well? Image motivation and monetary incentives in behaving prosocially. American Economic Review 99:544-555.

Auger, P. and T. M. Devinney. 2007. Do what consumers say matter? The misalignment of preferences with unconstrained ethical intentions. Journal of Business Ethics 76:361383.

Auriol, E. and S. Schilizzi, G. M. 2003. Quality Signaling through Certification. Theory and an Application to Agricultural Seed Markets. Mimeo, University of Toulouse.

Baksi, S. and P. Bose. 2007. Credence Goods, Efficient Labelling Policies, and Regulatory Enforcement. Environmental and Resource Economics 37:411-430.

Ballet, J. and A. Carimentrand. 2006. Le Commerce Equitable: Des Labels à l'Ethique Relationnelle. Mimeo.

Baron, D. P. 2001. Private Politics, Corporate Social Responsibility, and Integrated Strategy. Journal of Economics \& Management Strategy 10:7-45.

Baron, D. P. 2009. A Positive Theory of Moral Management, Social Pressure, and Corporate Social Performance. Journal of Economics \& Management Strategy 18:7-43.

Baron, D. P. 2010. Morally Motivated Self-Regulation. The American Economic Review 100:1299-1329.

Basu, A. K. and R. L. Hicks. 2008. Label Performance and the Willingness to Pay for Fair Trade Coffee: A Cross-National Perspective. International Journal of Consumer Studies 32:470-478.

Becker-Olsen, K. L., B. A. Cudmore, and R. P. Hill. 2006. The impact of perceived corporate social responsibility on consumer behavior. Journal of Business Research 59:46-53.

Becker, A., T. Deckers, T. Dohmen, A. Falk, and F. Kosse. 2012. The Relationship between Economic Preferences and Psychological Personality Measures. CESifo Working Paper Series.

Becker, G., M. DeGroot, and J. Marschak. 1964. Measuring Utility by a Single-Response Sequential Method. Behavioural Science 9:226-232. 
Becker, G. S. 1974. A Theory of Social Interactions. Journal of Political Economy 82:10631093.

Bekkers, R. 2005. Participation in Voluntary Associations: Relations With Resources, Personality, and Political Values. Political Psychology 26:439-454.

Bekkers, R. 2006. Traditional and Health-Related Philanthropy: The Role of Resources and Personality. Social Psychology Quarterly 69:349-366.

Bekkers, R. and T. Schuyt. 2008. And Who is Your Neighbor? Explaining Denominational Differences in Charitable Giving and Volunteering in the Netherlands. Review of Religious Research 50:74-96.

Bekkers, R. and P. Wiepking. 2011. A Literature Review of Empirical Studies of Philanthropy: Eight Mechanisms That Drive Charitable Giving. Nonprofit and Voluntary Sector Quarterly in press.

Bekkers, R. and M. O. Wilhelm. 2010. Helping Behavior, Dispositional Empathic Concern, and the Principle of Care. Social Psychology Quarterly 73:11-32.

Bellows, A. C., B. Onyango, A. Diamond, and W. K. Hallman. 2008. Understanding consumer interest in organics: production values vs. purchasing behavior. Journal of Agricultural \& Food Industrial Organization 6:1-28.

Ben-Ner, A. and A. Kramer. 2011. Personality and altruism in the dictator game: Relationship to giving to kin, collaborators, competitors, and neutrals. Personality and Individual Differences 51:216-221.

Ben-Ner, A., L. Putterman, F. Kong, and D. Magan. 2004. Reciprocity in a Two-part Dictator Game. Journal of Economic Behavior and Organization 53:333-352.

Bénabou, R. and J. Tirole. 2010. Individual and corporate social responsibility. Economica 77:1-19.

Bénabou, R. and J. Tirole. 2011. Identity, Morals and Taboos: Beliefs as Assets. Quarterly Journal of Economics 126:805-855.

Bennett, R. 2003. Factors underlying the inclination to donate to particular types of charity. International Journal of Nonprofit and Voluntary Sector Marketing 8:12-29.

Bergstrom, T., L. Blume, and H. Varian. 1986. On the private provision of public goods. Journal of public Economics 29:25-49.

Berkowitz, L. 1972. Social norms, feelings, and other factors affecting helping and altruism. Pages 63-108 in L. Berkowitz, editor. Advances in experimental social psychology. Elsevier, New York.

Besley, T. and M. Ghatak. 2007. Retailing Public Goods: The Economics of Corporate Social Responsibility. Journal of public Economics 91:1645-1663.

Blend, J. R. and E. O. van Ravenswaay. 1999. Measuring Consumer Demand for Ecolabeled Apples. American Journal of Agricultural Economics 81:1072-1077.

Bonroy, O. and C. Constantatos. 2004. Biens de Confiance et Concurrence en Prix: Quand Aucun Producteur ne Souhaite l'Introduction d'un Label. Revue Economique 55:527532.

Borghans, L., A. L. Duckworth, J. J. Heckman, and B. ter Weel. 2008. The Economics and Psychology of Personality Traits. Journal of Human Resources 43:972-1059.

Bougherara, D. and P. Combris. 2009. Eco-labelled food products: what are consumers paying for? European Review of Agricultural Econnomics 36:321-341.

Camerer, C. F. 2003. Behavioral Game Theory: Experiments in Strategic Interaction. Princeton, NJ: Princeton University Press; New York, NY: Russell Sage Foundation.

Caplan, B. 2003. Stigler-Becker versus Myers-Briggs: Why Preference-based Explanations are Scientifically Meaningful and Empirically Important. Journal of Economic Behavior and Organization 50:391-405. 
Carrigan, M. and A. Attalla. 2001. The myth of the ethical consumer - do ethics matter in purchase behaviour? Journal of Consumer Marketing 18:560-577.

Carrington, M., B. Neville, and G. Whitwell. 2010. Why Ethical Consumers Don't Walk Their Talk: Towards a Framework for Understanding the Gap Between the Ethical Purchase Intentions and Actual Buying Behaviour of Ethically Minded Consumers. Journal of Business Ethics 97:139-158.

Caswell, J. A. and E. M. Mojduszka. 1996. Using Informational Labeling to Influence the Market for Quality in Food Products. American Journal of Agricultural Economics 78:1248-1253.

Caswell, J. A. and D. I. Padberg. 1992. Toward a More Comprehensive Theory of Food Labels. American Journal of Agricultural Economics 74:460-468.

Cavaco, S. and P. Crifo. 2010. The CSR-Firm Performance Missing Link: Complementarity Between Environmental, Social and Business Behavior Criteria? WP series of Ecole Polytechnique 2010-19.

Chandon, P. and B. Wansink. 2011. Is Food Marketing Making us Fat? A Multidisciplinary Review. Foundations and Trends in Marketing in press.

Chatzidakis, A., S. Hibbert, and A. Smith. 2007. Why People Don't Take their Concerns about Fair Trade to the Supermarket: The Role of Neutralisation. Journal of Business Ethics 74:89-100.

Conrad, K. 2005. Price Competition and Product Differentiation When Consumers Care for the Environment. Environmental and Resource Economics 31:1-19.

Cornes, R. and T. Sandler. 1996. The theory of externalities, public goods, and club goods. Cambridge: Cambridge Univ. Press.

Costa, P. T. and R. R. McCrae. 1992. Revised NEO Personality Inventory and the Five-Factor Inventory professional manual. Psychological Assessment Resources, Odessa, FL.

Crampes, C. and A. Hollander. 1995. Duopoly and Quality Standards. European Economic Review 39:71-82.

Crane, A., A. McWilliams, D. Matten, J. Moon, and D. S. Siegel. 2008. The Oxford handbook of corporate social responsibility. Oxford University Press, USA.

Crumpler, H. and P. J. Grossman. 2008. An experimental test of warm glow giving. Journal of public Economics 92:1011-1021.

Dana, J., D. M. Cain, and R. M. Dawes. 2006. What you don't know won't hurt me: Costly (but quiet) exit in dictator games. Organizational Behavior and Human Decision Processes 100:193-201.

Darby, M. R. and E. Karni. 1973. Free competition and the optimal amount of fraud. Journal of law and economics 16:67-88.

Davies, R., B. 2005. Abstinence from Child Labor and Profit Seeking. Journal of Development Economics 76:251-263.

Davis, M. 1980. A Multidimensional Approach to Individual Differences in Empathy. JSAS Catalog of Selected Documents in Psychology 10.

De Pelsmacker, P., L. Driesen, and G. Rayp. 2005. Do consumers care about ethics? Willingness to pay for fair trade coffee. The Journal of Consumer Affairs 39:363-385.

DellaVigna, S., J. A. List, and U. Malmendier. 2012. Testing for Altruism and Social Pressure in Charitable Giving. The quarterly journal of economics forthcoming.

Doane, D. 2001. Taking Flight: The Rapid Growth of Ethical Consumerism. New Economics Fundation, London.

Eckel, C. and P. Grossman. 1996. Altruism in anonymous dictator games. Games and Economic Behavior 16:181-191.

Einolf, C. J. 2008. Empathic Concern and Prosocial Behaviors: A Test of Experimental Results Using Survey Data. Social Science Research 37:1267-1279. 
Eisenberg, N., P. A. Miller, M. Schaller, R. A. Fabes, J. Fultz, R. Shell, and C. L. Shea. 1989. The role of Sympathy and Altruistic Personality Traits in Helping: A Reexamination. Journal of Personality 57:41-67.

European Commission. 2001. Promoting a European framework for Corporate Social Responsibility. COM(2001) 366 final, Green Paper.

European Commission. 2006. Making Europe a pole of excellence on corporate social responsibility. COM(2006) 136 final, Communication.

Eurosif. 2010. European SRI Study.

Feddersen, T. J. and T. W. Gilligan. 2001. Saints and Markets: Activists and the Supply of Credence Goods. Journal of Economics \& Management Strategy 10:149-171.

Fong, C. M. 2007. Evidence from an Experiment on Charity to Welfare recipients: Reciprocity, Altruism and the Empathic Responsiveness Hypothesis. The Economic Journal 117:1008-1024.

Forsythe, R., J. L. Horowitz, N. E. Savin, and M. Sefton. 1994. Fairness in Simple Bargaining Experiments. Games and Economic Behavior 6:647-369.

Frey, B. S. and R. Jegen. 2001. Motivation crowding theory. Journal of Economic Surveys 15:589-611.

Friedman, M. 1970. The social responsibility of business is to increase its profits. New York Times Magazine 13:122-126.

Frooman, J. 1997. Socially Irresponsible and Illegal Behavior and Shareholder Wealth: A Meta-Analysis of Event Studies. Business and Society 36:221-249.

Gergen, K. J., M. Gergen, and K. Meter. 1972. Individiual Orientations to Pro-social Behavior. Journal of Social Issues 28:105-130.

Glazer, A., V. Kanniainen, and P. Poutvaara. 2010. Firms' ethics, consumer boycotts, and signalling. European Journal of Political Economy 26:340-350.

Golan, E., F. Kuchler, and L. Mitchell. 2001. Economics of Food Labeling. Journal of Consumer Policy 24:117-184.

Gordon, L. V. 1976. Survey of Interpersonal Values: Revised Manual. Science Research Associates, Chicago, IL.

Graziano, W. G. and N. Eisenberg. 1997. Agreeableness: A Dimension of Personality. Pages 795-824 in R. Hogan, J. Johnson, and S. Briggs, editors. Handbook of Personality Psychology. Academic Press, San Diego, CA.

Guillon, F. and M. Juliot. 2001. Les Attentes des Consommateurs s'Elargissent. Economie et Humanisme 357:18-21.

Hadden, S. G. 1986. Read the label: Reducing risk by providing information. Westview Press, Boulder, CO.

Hamilton, S. F. and D. Zilberman. 2006. Green markets, eco-certification, and equilibrium fraud. Journal of Environmental Economics and Management 52:627-644.

Harbaugh, R., J. W. Maxwell, and B. Roussillon. 2011. Label Confusion: The Groucho Effect of Uncertain Standards. Management Science 57:1512.

Harbaugh, W. T. 1998. The prestige motive for making charitable transfers. The American Economic Review 88:277-282.

Hartmann, M. 2011. Corporate social responsibility in the food sector. European Review of Agricultural Economics 38:297-324.

Heckman, J. J. and D. V. Masterov. 2007. The Productivity Argument for Investing in Young Children. Review of Agricultural Economics 29.

Hicks, R. L. 2006. Performance-Based Labeling.in U. Grote, A. K. Basu, and N. H. Chau, editors. New Frintiers in Eco and Social Labeling. Physica-Verlag, Springer Publishing, Berlin and New York. 
Hines, C. and A. Ames. 2000. Ethical Consumerism. A Research Study Conducted for the Co-Operative Bank by MORI. MORI, London.

Horváthová, E. 2010. Does environmental performance affect financial performance? A metaanalysis. Ecological Economics 70:52-59.

Huang, C. L. 1996. Consumer preferences and attitudes towards organically grown produce. European Review of Agricultural Economics 23:331.

Hvide, H. K. 2009. Oligopolistic Certification. The B.E. Journal of Theoretical Economics 9.

Kitzmueller, M. and J. Shimshack. 2012. Economic Perspectives on Corporate Social Responsibility. Journal of Economic Literature 50:51-84.

Konow, J. and J. Earley. 2008. The hedonistic paradox: is homo economicus happier? Journal of public Economics 92:1-33.

KPMG. 2008. KPMG International survey of corporate responsibility reporting.

Kuhn, M. 2005. The Greening of Markets: Product Competition, Pollution and Policy Making in a Duopoly. Elgar, Cheltenham.

Lantos, G. P. 2001. The boundaries of strategic corporate social responsibility. Journal of consumer marketing 18:595-632.

Ledyard, J. O. 1995. Public Goods: A Survey of Experimental Research.in A. Roth and J. Klage, editors. Handbook of Experimental Economics. Princeton University Press, Princeton, NJ.

Levitt, S. D. and J. A. List. 2007. What Do Laboratory Experiments Measuring Social Preferences Reveal About the Real World? The Journal of Economic Perspectives 21:153-174.

Loureiro, M. L. and J. Lotade. 2005. Do Fair Trade and Eco-Labels in Coffee Wake Up the Consumer Conscience? Ecological Economics 53:129-138.

Loureiro, M. L., J. J. McCluskey, and R. C. Mittelhammer. 2002. Will Consumers Pay a Premium for Eco-labeled Apples? The Journal of Consumer Affairs 36:203-219.

Margolis, J. D., H. A. Elfenbein, and J. P. Walsh. 2008. Does it pay to be good? An analysis and redirection of research on the relationship between corporate social and financial performance. Working Paper. Harvard University.

McCluskey, J. J. 2000. A Game Theoretic Approach to Organic Foods: An Analysis of Asymmetric Information and Policy. Agricultural and Resource Economics Review 29:1-9.

McCluskey, J. J. and M. L. Loureiro. 2003. Consumer preferences and Willingness to Pay for Food Labeling: A Discussion of Empirical Studies. Journal of Food Distribution Research 34:95-102.

McGarry Wolf, M., B. Johnson, K. Cochran, and L. Hamilton. 2002. Consumer attitudes toward organically grown lettuce. Journal of Food Distribution Research 33:155-160.

McWilliams, A. and D. Siegel. 2000. Corporate social responsibility and financial performance: correlation or misspecification? Strategic Management Journal 21:603609.

Mohr, L. A., D. J. Webb, and K. E. Harris. 2001. Do Consumers Expect Companies to be Socially Responsible? The Impact of Corporate Social Responsibility on Buying Behavior. Journal of Consumer Affairs 35:45-72.

MORI, L. 2000. European Attitudes towards Corporate Social Responsibility. Research for CSR Europe. MORI, London.

National Academy of Sciences. 1991. Improving America's Diet and Health: From Recommendations to Action. National Academy Press, Report of the Committee on Dietary Guidelines Implementation, Food and Nutrition Board, Institute of Medicine. Washington, D.C. 
Nelling, E. and E. Webb. 2009. Corporate social responsibility and financial performance: the "virtuous circle" revisited. Review of Quantitative Finance and Accounting 32:197209.

Nelson, P. 1974. Advertising as information. The Journal of Political Economy 81:729-754.

Noussair, C. N. and B. Ruffieux. 2004. A Comparison of Hedonic Rating and DemandRevealing Auctions. Food Quality and Preference 15:393-402.

Nyborg, K. and M. Rege. 2003. Does public policy crowd out private contributions to public goods. Public Choice 115:397-418.

Offerman, T., J. Sonnemans, and A. Schram. 1996. Value Orientations, Expectations and Voluntary Contributions in Public Goods. The Economic Journal 106:817-845.

Palfrey, T. R. and H. Rosenthal. 1984. Participation and the provision of discrete public goods: a strategic analysis. Journal of public Economics 24:171-193.

Park, E.-S. 2000. Warm-Glow versus Cold-Prickle: A Further Experimental Study of Framing Effects on Free-Riding. Journal of Economic Behavior and Organization 43:405-421.

Penner, L. A. 2002. Dispositional and Organizational Influences on Sustained Volunteerism: An Interactionist Perspective. Journal of Social Issues 58:447-468.

Penner, L. A., B. A. Fritzsche, J. P. Craiger, and T. S. Freifeld. 1995. Measuring the Prosocial Personality. Pages 147-163 in C. D. Spielberger and J. N. Butcher, editors. Advances in Personality Assessment. Erlbaum, Mahwah, NJ.

Perugini, M., J. H. W. Tan, and D. J. Zizzo. 2010. Which is the More Predictable gender? Public Good Contribution and Personality. Economic Issues 15:83-110.

Poret, S. 2007. Les défis du commerce équitable dans l'hémisphère Nord. Économie rurale:56-70.

Reed, P. B. and L. K. Selbee. 2002. Is There a Distinctive Pattern of Values Associated with Giving and Volunteering? The Canadian case. 32nd ARNOVA Conference, Montreal, Canada.

Rege, M. and K. Telle. 2004. The impact of social approval and framing on cooperation in public good situations. Journal of public Economics 88:1625-1644.

Renaut, A. 2003. Corporate social responsibility in Europe: A chance for social dialogue?in ILO, editor. Labour Education. ILO, Geneva.

Ribar, D. C. and M. O. Wilhelm. 2002. Altruistic and joy-of-giving motivations in charitable behavior. The Journal of Political Economy 110:425-457.

Rode, J., R. M. Hogarth, and M. Le Menestrel. 2008. Ethical Differentiation and Market Behavior: An Experimental Approach. Journal of Economic Behavior and Organization 66:265-280.

Roe, B. and I. Sheldon. 2007. Credence Good Labeling: The Efficiency and Distributional Implications of Several Policy Approaches. American Journal of Agricultural Economics 89:1020-1033.

Ruffieux, B. 2004. Le Nouveau Citoyen-Consommateur: Que Peut-On en Attendre en Termes d'Efficacité Economique? Sciences de la Société 62:93-117.

Schäfer, H., J. Beer, J. Zenker, and P. Fernandes. 2006. Who is who in Corporate Social Responsibility Rating? A survey of internationally established rating systems that measure Corporate Responsibility. Bertelsmann Foundation.

Sen, S. and C. B. Bhattacharya. 2001. Does Doing Good Always Lead to Doing Better? Consumer Reactions to Corporate Social Responsibility. Journal of Marketing Research 38:225-243.

Simon, H. A. 1993. Altruism and economics. The American Economic Review 83:156-161.

Smith, N. C. 2007. Consumers as drivers of corporate responsibility.in A. Crane, A. McWilliams, D. Matten, J. Moon, and D. S. Siegel, editors. The Oxford Handbook of corporate social responsibility. Oxford University Press, USA. 
Social Investment Forum. 2003. 2003 Report on Socially Responsible Investing Trends in the United States. SIF Industry Research Program.

Soetevent, A. R. 2005. Anonymity in giving in a natural context--a field experiment in 30 churches. Journal of public Economics 89:2301-2323.

Surroca, J., J. A. Tribó, and S. Waddock. 2010. Corporate responsibility and financial performance: the role of intangible resources. Strategic Management Journal 31:463490.

Tagbata, D. and L. Siriex. 2008. Measuring Consumer's Willingness to Pay for Organic and Fair Trade Products. International Journal of Consumer Studies 32:479-490.

Teisl, M. F., N. E. Bockstael, and A. Levy. 2001. Measuring the Welfare Effects of Nutrition Information. American Journal of Agricultural Economics 83:133-149.

Teisl, M. F. and B. Roe. 1998. The Economics of Labeling: An Overview of Issues for Health and Environmental Disclosure. Agricultural and Resource Economics Review 27:140150.

US-Sif. 2010. Report on Socially Responsible Investing Trends in the United States.

Valor, C. 2008. Can consumers buy responsibly? Analysis of solutions for market failures Journal of Consumer Policy 31:315-326.

Van Lange, P. A. M. 2000. Beyond Self-Interest: A Set of Propositions Relevant to Interpersonal Relations. Pages 75-104 in W. Stroebe and M. Hewstone, editors. European Review of Social Psychology. Wiley, London.

Van Lange, P. A. M., W. Oten, E. M. N. De Bruin, and J. A. Joireman. 1997. Development of Prosocial, Individualistic, and Competitive Orientations: Theory and Preliminary Evidence. Journal of Personality and Social Psychology 73:733-746.

Vermeir, I. and W. Verbeke. 2006. Sustainable food Consumption: Exploring the consumer "Attitute - Behavioral Intention" gap. Journal of Agricultural \& Environmental Ethics 19:169-194.

Vogel, D. 2005. The market for virtue: The potential and limits of corporate social responsibility. Brookings Inst Pr.

Waddock, S. A. and S. B. Graves. 1997. The corporate social performance. Strategic Management Journal 8:303-319.

Wertenbroach, K. and B. Skiera. 2002. Measuring Consumer's Willingness to Pay at the Point of Purchase. Journal of Marketing Research 39:228-241.

Wright, P. and S. P. Ferris. 1997. Agency conflict and corporate strategy: The effect of divestment on corporate value. Strategic Management Journal 18:77-83.

Wymer, W. W. 1997. Segmenting volunteers using values, self-esteem, empathy, and facilitation as determinant variables. Journal of Nonprofit \& Public Sector Marketing $5: 3-28$. 